\title{
Internet Telephony: Effects on the Universal Service Program in the United States
}

\author{
MARTHA GARCÍA-MURILLO * \\ School of Information Studies, Syracuse University \\ LEE W. MCKNIGHT \\ School of Information Studies, Syracuse University
}

\begin{abstract}
Internet phone services have grown from technical novelty to a competitive threat for traditional circuitswitched telecommunications. Using available telecommunication deployment statistics in the United States and modeling software, this paper presents two scenarios that investigate the potential impact of Internet telephony on universal service programs. They test whether the introduction of this technology and the way it could potentially be regulated would sufficiently reduce contributing carriers' revenues to threaten the viability of the Universal Service Program. We conclude that the regulatory policies developed in the past century to support universal service have been obsolesced by the innovation and creative destruction of Internet telephony.
\end{abstract}

\section{Introduction}

Internet telephony, also known as Voice over Internet Protocol (VoIP), Internet calling, or Internet phone, is a technology that is revolutionizing the communications market. The process of creative destruction that is likely to emerge from disruptive technologies like VoIP has the potential of reducing prices, accelerating the rate of innovation, and making advanced services affordable and accessible to the greater population.

There are many factors that make VoIP a disruptive technology. From a technological perspective, VoIP can use existing fixed and wireless networks more efficiently. This could allow the introduction of other more advanced services using the same infrastructure. At the industry level traditional voice carriers will be forced to replace their voice services with VoIP but not without trying to delay this transition. Regulation for this service will also be challenged. Just as firms find it difficult to give up older technologies that have become profitable "cash cows," so too have telecommunications regulators in the U.S., whether at the state or federal level, been unable to give up the easy money of overregulation. This includes excessive and unnecessary licensing fees, access charges and

* Contact author: School of Information Studies, Hinds 220, Syracuse University, NY 13244-4100, United States. E-mail: $\underline{\text { mgarciam@syr.edu }}$ 
taxes; some left over from the Spanish-American War in the case of the U.S. According to a recent World Bank study (World Bank, 2005), inefficient institutions - in the form of regulations and government agencies - are one of the biggest obstacles to investment.

One of the areas where VoIP is likely to have an important, potentially negative, impact is the universal service fund. In this study we developed a model that attempts to determine how two types of VoIP regulation are likely to affect its feasibility.

The paper is organized in four sections including this introduction. Section 2 presents the concept of creative destruction, disruptive technologies and provides background information about VoIP. It also describes the reasons why VoIP is a revolutionary service for both the communications industry and regulators. Section 3 presents a simple model that illustrates the impact of VoIP on universal service policies. The last section presents conclusions and implications.

\section{Disruptive technology, VolP and regulation}

Innovation enables growth and change even as competitors destroy some firms with obsolete technologies. Joseph Schumpeter writing in the first half of the twentieth century, called this process "creative destruction", which highlights both the positive and negative aspects of technological and industrial change. New jobs, firms and industries are created even as jobs are lost and firms are shut down by new technologies. In addition to the effects of the Internet bubble, some argue (Baumol, 2001 and McKnight, 2001) the Internet and telecommunications industries have already seen their fair share of "creative destruction'. Of course the innovation has not stopped.

The concept of creative destruction, as a general phenomenon, can be studied more closely in terms of the characteristics of especially novel technologies likely to have widespread industrial effects. To describe those technologies, Christensen (2000) proposed the concept of disruptive technologies. In his study of corporations that failed, he found, just as Schumpeter had decades earlier, that there are some technologies that have the capacity to change the dynamics of a marketplace at the expense of the existing established corporations and products. These technologies are able to provide value to consumers at a comparatively lower cost. One of the reasons why these technologies have tended to have such devastating effects on incumbents is because many of them are substitutes for existing products and services, which compete directly with those that already exist in the market. Christensen explains that one of the reasons why incumbents tend to lose their advantage over the new entrants is because these new products exhibit, for the most part, lower revenue margins and tend to cannibalize existing product offerings. Unable to respond without losing profits, companies begin to experience an erosion of their market share.

\subsection{VolP and traditional voice carriers}

Internet telephony applications were originally developed to allow voice communication among computers, referred to as PC-to-PC over Internet protocol (IP). As the technology evolved, it was possible to call a telephone subscriber on the public switched telephone network. The more advanced form of Internet telephony, which Clark (2001) calls Class 1 applications, allows the use of the Internet to make voice connections among people using their traditional telephone equipment. 
There are several reasons why VoIP can be considered a disruptive technology for traditional telephone operators. First, Internet telephony services are charged in buckets of minutes. These minutes include both local and national long distance calls, including Canada. The traditional carriers, on the other hand, charge on a per minute basis for toll and international connections, in addition to monthly fees for local calls. Because of differences in tariffs, traditional carriers are bound to lose revenue as a result of market share losses. They will be forced to change their tariff regimes.

Second, even before new entrants began to offer telephony using the public Internet, traditional carriers delayed the introduction of broadband service through their DSL technology. Before DSL, subscribers connected to the Internet by dialing up to their Internet Service Provider. Because this connection tied up the line it was not possible for an individual to make or receive calls at the same time. This benefited telephone carriers because people began to order second lines. DSL, which splits the line to allow for data and voice to be carried on the same network, obviates the need of a second voice line. It is thus not surprising that traditional carriers delayed the introduction of this service, as with one line users could get both Internet access and basic telephony service - often at a lower price than two lines. The new network architectures built on Internet technologies enables new entrants to enter markets that previously could only be reached by tremendous investment in physical infrastructure. Internet telephony service providers can enter from any number of directions, and may require only minimal investment (McKnight and Leida, 2001; Young, 2005).

Third, revenues from traditional phone lines came not only from the subscribers but also from the termination charges that the local carriers obtained from the long distance telephone providers. VoIP carriers are not currently paying these termination charges.

The reason why traditional telecommunications carriers are now beginning to adopt IPbased communication is because the entry of new firms offering substitute services has forced them to respond to the challenge and provide these services. It was the entry of cable companies into the provision of data that accelerated DSL offerings. According to Walsh et al. (2002), "established firms rarely commercialize disruptive technologies and they prefer to use market-pull strategies to accomplish this".

The slow pace of innovation is in part due to regulation and to benefits from the monopolized market, which companies have tried to defend even after government efforts at liberalization. As stated by Caballero and Hammour (1996), part of the reason why companies fail to adapt to the changing environmental circumstances is because making transitions is slow. The high transaction costs involved in the process of change, as well as government policy, can further exacerbate what Caballero calls "technological sclerosis".

In the process of transformation, companies have generally relied on a series of competitive weapons, used on an as-needed basis, to fend off new challengers and the process of creative destruction (Stein, 1997). These generally have included, for example: customer inertia; the control of essential facilities; established national networks; and vertically developed and integrated production facilities, which include local, long distance and wireless offerings (Intven et al., 2000).

In addition to the traditional business-related competitive resources that they have at their disposal, they also have other policy-related resources. As pointed out by GarcíaMurillo (2004), companies can make strategic use of the courts to delay the entry of new competitors - a strategy that she has termed "legal play." Incumbent carriers have challenged government decisions in state courts. These legal battles have taken years to 
resolve, thus buying time for them to cream the last drop of their monopoly rents while improving their networks to provide more advanced services. This has also been facilitated because U.S. courts are able to overrule Federal Communications Commission (FCC) decisions.

The existence of highly reliable networks is also forcing independent VoIP carriers to improve the technology to the point that their offerings are of similar quality. Technological advances have resulted in a migration towards this service. There are several reasons why this is happening. First and foremost, the cost of a call is considerably cheaper. Vonage, one of the most well known companies, charges $\$ 15$ per month for 500 minutes of local, domestic and international calls to Canada. For $\$ 25$, customers can obtain unlimited access. The service includes caller ID, three-way calling, call waiting, call forwarding, call transfer and repeat calling. This compares favorably with a company such as Verizon that charges between $\$ 48$ and $\$ 55$ for an unlimited package with similar added value services. This does not include toll calls that incur additional usage charges.

The migration is also happening at the corporate level. As described by Greenblatt (2003), companies can take advantage of their networks to offer voice connections as well. This alternative is less expensive than the leased lines that they traditionally contract from the phone company. It also allows for better network utilization and simplified network management because both voice and data can be integrated. This obviates the need for the staff that previously managed the voice connections. Companies can potentially become more productive, given the additional features that are possible with the computer telephony integration that Internet telephony makes possible.

\subsection{Regulation of VolP}

VoIP is also a disruptive technology for the government and the FCC in particular because this service does not fit into the existing legal code that regulates the industry. The Telecommunications Act of 1996 makes a distinction between "information" and "telecommunications." Information services are defined in the Act as "the offering of a capability for generating, acquiring, storing, transforming, processing, retrieving, utilizing, or making available information via telecommunications." These services are largely unregulated. Telecommunication services, in contrast, are subject to the Title II section of the Act that requires contributions to the universal service fund. They are subject to access charges and rate regulation.

In the early 1990s, when VoIP regulation was first considered, the FCC decided not to regulate it as a common carrier. At that time there were still many quality problems and it was not possible yet to use a traditional handset to make calls using the Internet. Recently, the FCC requested comments to guide the agency's decision regarding the regulatory treatment of VoIP. The issues to be decided include access charges, wiretapping obligations, emergency 911 and universal service contributions. Two recent tragedies ${ }^{1}$ have forced the FCC to require VoIP carriers to comply with E-911 obligations (Wigfield, 2005). The FCC has not yet decided on the other issues since it first submitted its notice of proposed rulemaking in February 2004, but the former chairman, Michael Powell, stated on several occasions that it should remain unregulated. If this is the case, then Internet

\footnotetext{
${ }^{1}$ In Houston, TX a teenager was unable to call an ambulance after her parents were shot as a result of a home robbery in February of 2005. A baby died the same year for similar reasons. The problem is that VoIP carriers route 911 calls to public safety administrative offices instead of directly sending the calls to Public Service Answering Points and there are some VoIP that do not offer 911 services.
} 
voice providers will not have to contribute to the universal service fund. They also do not have to pay access fees or settlement rates to local or foreign carriers.

Traditional telecommunications operators are likely to remain regulated as common carriers and will have to pay these fees. The fear is that under such circumstances the revenue base, from which contributions to the universal service fund are made, will decrease, thus negatively affecting the fund's finances.

But will this disruptive technology severely affect the revenue stream of traditional carriers and negatively affect any further investment in telecommunications infrastructure? In our view, Internet telephony will lead to creative destruction, whereby innovations would destroy existing technologies and methods of production, only to be assaulted themselves by imitative rival products with newer, more efficient configurations (McKnight et al. 2001) - in both the private and the government sector - through the reconfiguration of regulation and the legislation that is likely to accompany this technological evolution. In this process of adjustment one of the programs that is likely to experience significant changes is the Universal Service Program (USP).

\section{VolP and the Universal Service Fund}

Until the 1996 Telecommunications Act, universal service was generally conceived as the provision of basic telephone services to residential users (Bar and Riis, 2000). It was not until the Act was passed that the definition was formalized and expanded to include libraries, schools and rural health care clinics. The scope of services to be subsidized was also expanded to include computer equipment and Internet access.

The program relies on the contribution of telecommunication carriers who pay a fee proportional to their interstate and international revenues. These include long distance carriers, local telephone companies, wireless telephone providers, paging companies and payphone providers. The percentage is called the contribution factor.

The Universal Service Administrative Company (USAC) is the agency responsible for administering the funds. Even though there have been substantial price declines in technology, ${ }^{2}$ disbursements from the universal service fund have increased. Figure 1 shows the USAC disbursements from 1998 to 2003. Of the four programs that the universal service fund supports, all experienced increases except for school and libraries. ${ }^{3}$ One explanation for this increase in disbursements is the need that many rural carriers have had to upgrade their telecommunications infrastructure. Many small rural operators have networks that were established 30 or 40 years ago. Northwest Telephone Cooperative Association, for example, which provides services to rural Iowa, had to replace infrastructure originally installed in 1963 (Universal Service Administrative Company Annual Report, 2003).

\footnotetext{
${ }^{2}$ During the 1992-1999 period, the price of semiconductor devices used in communications equipment and in computers declined at a compound annual growth rate of 12 percent and 32 percent per year, respectively. (Aizcorbe, Flamm, and Khurshid, 2001)

${ }^{3}$ The universal service fund supports four programs: 1) high cost, which supports the provision of services to primarily rural areas; 2) low income, which provides support to households with low means; 3) rural health care support; and 4) schools and libraries support.
} 


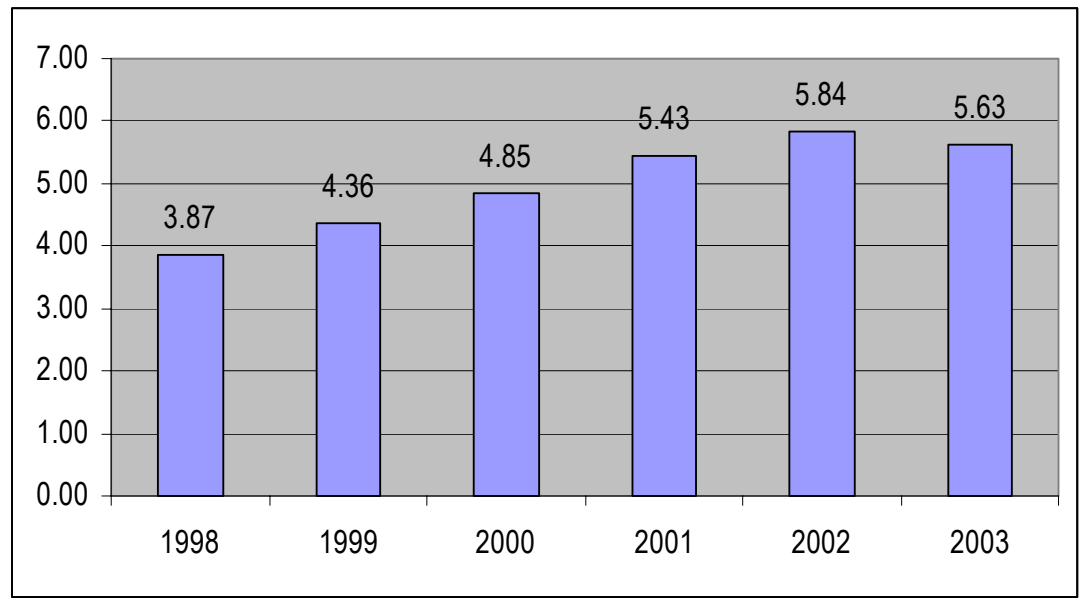

\section{Figure 1: USAC overall disbursements (\$ billions)}

Source: (Universal Service Administrative Company Annual Report, 2002)

VoIP has the potential to negatively affect this program because this technology, as explained in the previous section, will lead to a reduction in revenues, which in turn will lead to lower contributions.

Additionally the Universal Service Program is facing greater demands as many people believe that it should be expanded to include computer literacy and end user equipment (Gillett, 2000), training and education to cultivate human capacity \{Lievrouw, 2000\} and to take into consideration disability needs (Goggin and Newell, 2000).

Because $95 \%$ of the population has a telephone line (Albery, 1995; Belinfante, 1993) some scholars have proposed eliminating the current Universal Service Program. They believe that market forces can more effectively achieve these broader goals. Mueller (1993), for example, has argued that a universal service should no longer entail the physical presence of a wire to a person's house but instead the means by which the household can pay for these services. This is particularly true now that there has been an increasing interest in expanding the universal service fund to finance broadband access.

Given declining revenues it is unlikely that the universal service fund could finance existing and desired needs. In addition, high phone line penetration and the emergence of new technologies such as VoIP could require that the Universal Service Program be reformed or perhaps eliminated. In the following section we describe the effect that two VoIP regulatory regimes could have on the Universal Service Program.

\subsection{Simulation}

New technologies have always been a challenge for regulators. They enter the market inconspicuously and their potential, more than their actual performance, appear to disrupt the market and negatively affect the incumbent players. Internet telephony is one of these technologies, but it is only one among the many more that will continue to appear.

The greatest challenge for regulators is their inability to determine, in the long term, the impact that these technologies can have on the market, the existing regulatory framework and social goals. Scholars face similar problems. It is difficult to determine (without any data) whether or not these new technologies have a negative or positive impact on society. The lack of field data prevents us from using econometric tools to 
analyze and evaluate the effects of two regulatory alternatives regarding the contribution of VoIP to the universal service fund. Because of this, we use instead, with the help of iThink ${ }^{\circledR}$ modeling software, a simulation that allows us to determine the impact of Internet telephony on universal service obligations.

The model, which is a simplified abstraction developed for analytic purposes, consists of three main components: 1) the market where market share is determined; 2) household expenditures on voice communication services; and 3) the universal service fund. Figure 2 shows the interrelations between all of the model components.

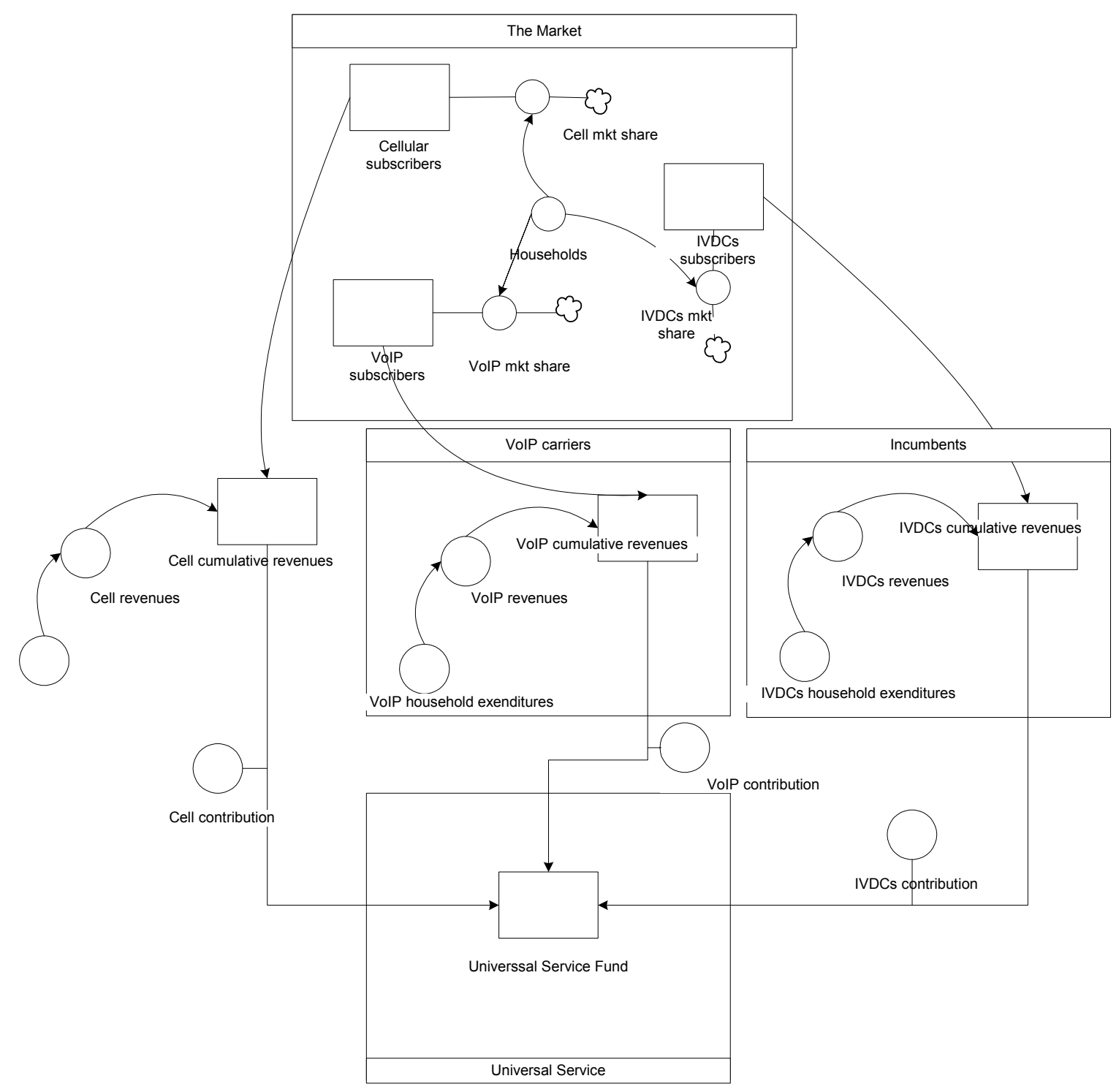

Figure 2: Model for universal service contributions simulation

The first component corresponds to the telecommunications market. It is a simplified model where one type of firm represents all of the players in that category. The three types of carriers are: VoIP, cellular, and incumbent voice and data carriers (IVDC). The model assumes that these three technologies provide comparable services. The market shares for 
VoIP and cellular were included in the model as external variables. The share of the incumbents, because it depends on the gains or loses that they make with respect to other alternatives, was determined as a function of those two. Thus incumbent market share $(I M k S)$ will increase or decrease depending on whether the competitors' share increases or decreases:

\section{$I M k S=f(C e l l M k S$, VoIPMkS $)$}

The initial market share was determined from existing FCC and industry data. From this point, we are able to change the market share based on adoption trends of other technologies (such as broadband, which is necessary for VoIP to work).

The second component corresponds to the yearly revenues of the three types of carriers. These are determined by household communications expenditures. The model assumes a stable number of households who need voice services. According to the FCC (2003), there are 127.1 million residential and single-line business lines. Of these, 103.7 million are calculated to be primary lines. Among these residential lines, 6.3 million are part of the Federal Lifeline program, which is approximately $6 \%$ of the lines.

Households can spend income allocated for communication services to pay for a wireless connection, a wired line, or a VoIP phone. Phone household expenditures have experienced two types of effects running in opposite directions. The first one is the increases in expenditures that the FCC has reported over the years. The Reference Book of Rates (Zimmerman, 2004) states that there has been an $8 \%$ increase in telephone expenditures over the $1992-2003$ period. In the 15 year model we assume a 5\% increase in expenditure because it has been shown that, as the price of communication drops, the amount of time that people spend communicating increases. These increases in annual phone expenditures effectively mean that the carriers are obtaining higher revenues per household. In addition, wireless expenditures have also increased dramatically. In 1995 the average annual household expenditure was $\$ 82$, while eight years later this had increased to $\$ 492$. While we do not expect such large increases in the next 15 years, we may still see another 30\% increase. This assumption is based on the fact that there are other countries in the world like Hong Kong, the UK, Italy, Spain, Finland where mobile penetration is more than 90\% (Annual Report and Analysis of Competitive Market Conditions with Respect to Commercial Mobile Services, 2004). This means that there is potentially another $30 \%$ of the population that could use a cell phone given the current cellular penetration in the US of approximately $55 \%$.

The other effect is related to the drop in prices that communications services are experiencing. Over the same 11 year period, the FCC reported a decrease in long distance rates of 53\%. In 1999 the revenue per minute was $\$ 0.15$, while in 2003 it had decreased to \$0.07 (Trends in Telephone Service, 2005).

Taking into consideration these two effects, the model begins with an annualized wired toll household expenditure of $\$ 122$, which drops to $\$ 60$ in the simulation. Cellular expenditures are modeled to rise from a current rate of $\$ 98.00$ to $\$ 130.00$ in 15 years, mostly due to increased penetration in the household, and VoIP expenditure is calculated to go from $\$ 180$ to $\$ 108$. These household expenditures were calculated from the most recent FCC report on telephone trends (Trends in Telephone Service, 2005). 
The revenue for carriers is simply determined by the quantity demanded in the form of market share times the annualized household expenditure for the service. Table 1 presents the system of equations that were used in the iThink ${ }^{\circledR}$ modeling software.

\begin{tabular}{|l|l|l|}
\hline \multicolumn{1}{|c|}{$\begin{array}{c}\text { Model } \\
\text { Component }\end{array}$} & \multicolumn{1}{|c|}{ Formula } & \multicolumn{1}{c|}{ Explanation } \\
\hline $\begin{array}{l}\text { IVDC } \\
\text { Market share }\end{array}$ & $\begin{array}{l}1-\text { (cellular Mkt share + VoIP Mkt } \\
\text { share) }\end{array}$ & $\begin{array}{l}\text { The initial market shares for cellular } \\
\text { and VoIP carriers were assumed to be } \\
4 \% \text { and 1\%, respectively. }\end{array}$ \\
\hline IVDC Revenues & $\begin{array}{l}\text { Number of IVDC subscribers x } \\
\text { household expenditures }\end{array}$ & $\begin{array}{l}\text { Total number of subscribers times the } \\
\text { annualized household expenditure for } \\
\text { the service. }\end{array}$ \\
\hline $\begin{array}{l}\text { Cellular carriers } \\
\text { revenue }\end{array}$ & $\begin{array}{l}\text { Number of cellular subscribers x } \\
\text { household expenditures }\end{array}$ & $\begin{array}{l}\text { Total number of subscribers times } \\
\text { household expenditures. }\end{array}$ \\
\hline $\begin{array}{l}\text { VoIP Revenue } \\
\text { humber of VoIP subscribers x }\end{array}$ & $\begin{array}{l}\text { Total number of subscribers times } \\
\text { household expenditures. }\end{array}$ \\
\hline $\begin{array}{l}\text { Number } \\
\text { of households }\end{array}$ & $127,000,000$ & $\begin{array}{l}\text { Total number of households with a } \\
\text { phone line in the U.S. }\end{array}$ \\
\hline $\begin{array}{l}\text { IVDC } \\
\text { household } \\
\text { expenditure }\end{array}$ & Constant & $\begin{array}{l}\text { We calculated that the annual } \\
\text { expenditure for IVDC toll services is } \\
\text { approximately \$122. }\end{array}$ \\
\hline $\begin{array}{l}\text { Cellular } \\
\text { household } \\
\text { expenditure }\end{array}$ & Constant & $\begin{array}{l}\text { We calculated the annual expenditure } \\
\text { of cellular use to be \$210. }\end{array}$ \\
\hline $\begin{array}{l}\text { VoIP household } \\
\text { expenditure }\end{array}$ & Constant & $\begin{array}{l}\text { We calculated the annualized VoIP } \\
\text { expenditure to be \$180. }\end{array}$ \\
\hline
\end{tabular}

Table 1: Definition of model components for household expenditures

The third component of the model corresponds to the universal service fund. The sources of funding for the program come from carrier contributions. The contributions for the model come from the FCC official contribution factor.

We simulated two scenarios. The first represents the status quo where VoIP providers do not contribute to the universal service fund while traditional carriers do. In the second, the parity scenario, VoIP carriers are required to contribute to the universal service fund, just as the traditional carriers do.

\subsection{Status Quo Scenario}

In the first scenario we simulate the status quo. Traditional carriers contribute to the fund while the VoIP carriers do not. The interstate and international end-user revenues contribution used for the simulation was $11.1 \%$, which is the current contribution established by the FCC (FCC, 2005).

We calculated revenue of VoIP operators based on the current 1 million users. According to industry trade news, there are an additional one million users who make free Internet calls through broadband connections (Brown, 2004). At the same time we simulated traditional wireline connections to decline over the 15 year period, it is expected that voice services through the Internet will increase. Using this forecast we develop a 
model where we could see how changes in market share can affect the revenues of all carriers.

The model starts with a VoIP market share of $1 \%$, which increases to $50 \%$ with the consequent decrease in market share of traditional and wireless telephony. The contribution factor was increased to $20 \%$ for the 15 year period. The increase to $20 \%$ is not infeasible considering that the contribution factor has been increasing in recent years. For example, in 2000 the contribution factor was 0.055 ; in 2002 it was 0.087735 , which was a significant increase from the second quarter of that year, calculated at 0.072805 . According to FCC documents, the contribution has been increasing one tenth of a percent per year. We assume that as people migrate from traditional to IP-based telephony the current carriers will have to increase their contributions to cover the $\$ 6.5$ billion that the Universal Service Administrative Company (USAC) reported in its latest annual report (Universal Service Administrative Company Annual Report, 2004).

Figure 3 shows the numerical results of this simulation. The revenues for both the IVDCs decrease as a result of a decline in both price and market share.

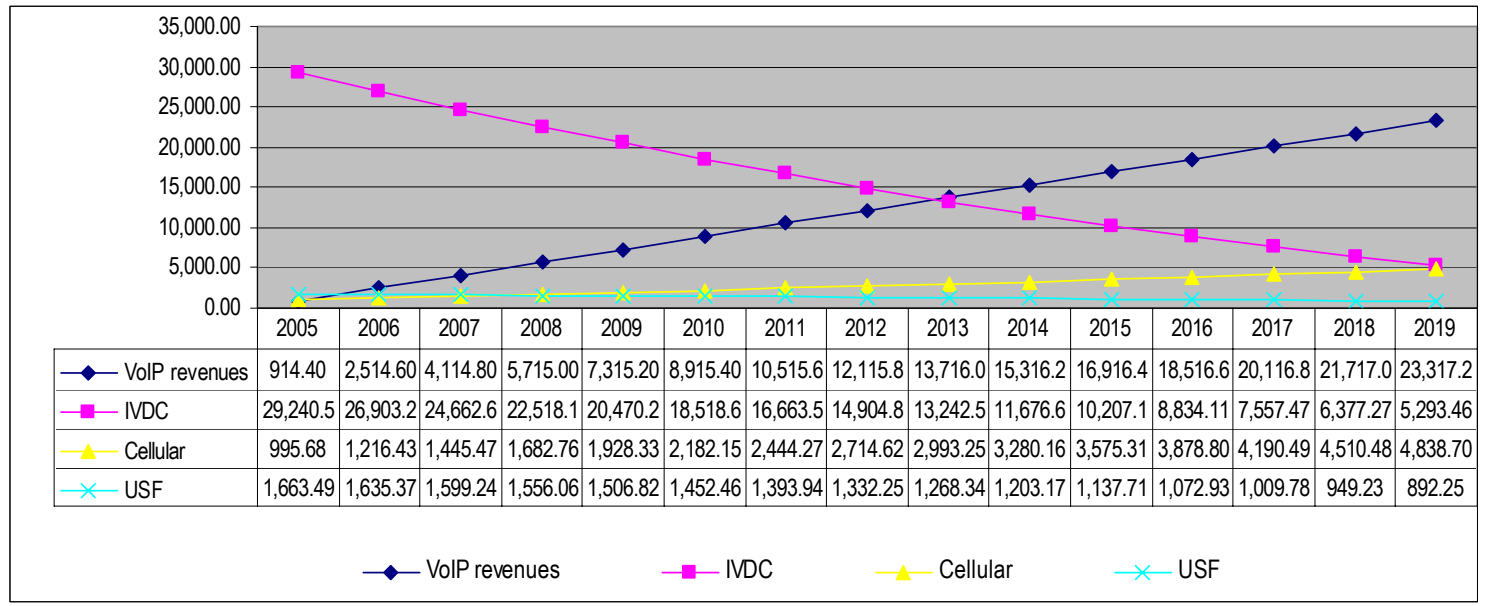

Figure 3: Incumbents, cellular, VoIP revenues and USP fund contributions with VoIP not contributing to the USP (\$ millions)

Under those circumstances we see that even with an increase in the USP contributions from IVDCs, the Universal Service Program fund revenues experience a considerable decline $(45 \%)$ over the 15 year period. According to the FCC the fund will require approximately $\$ 6,000$ billion per year for all USP programs. Given the strong growth of IP telephony and the aggressive price competition that both IP phone providers and cellular providers are offering, it is unlikely that the FCC will achieve its projection under this scenario.

\subsection{Parity scenario}

Figure 4 shows the result of the second simulation. Here VoIP providers contribute to the Universal Service Program. Their contribution starts at $11 \%$ and is gradually increased to $20 \%$ over the 15 year period. Under this scenario the universal service fund almost doubles the initial amount. When VoIP carriers contribute the USP could be sustained for a longer period. 


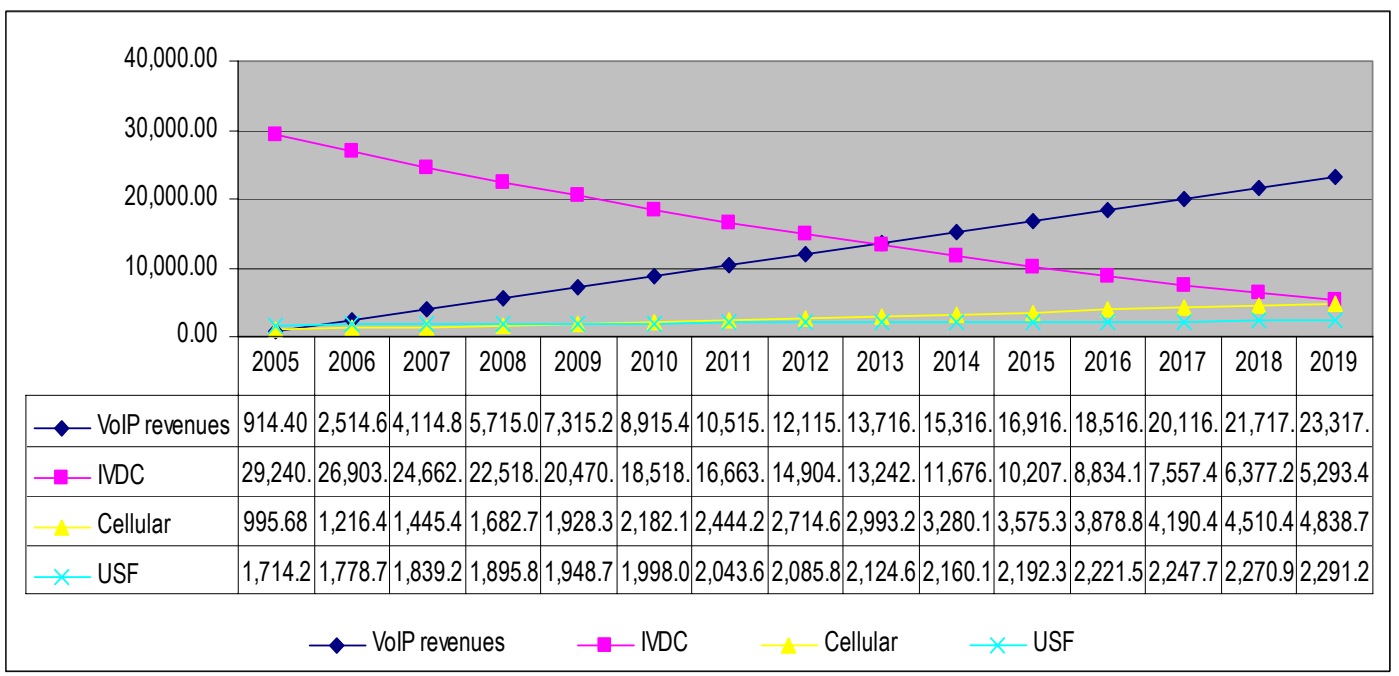

Figure 4: IVDC, VoIP Revenues and USP Contributions with VoIP Contributing To The USP (\$ millions)

These two simulations thus indicate that the type of VoIP regulation with respect to universal service contributions will have an important effect on the Universal Service Program. The status quo scenario shows that without VoIP contributions the USP is unsustainable. This is likely to be exacerbated by FCC decisions that have categorized several communication services as information services. An example is the recent Brand X Supreme Court decision where access to the Internet using the cable TV infrastructure is considered an "information service" and thus not subject to the Title II requirements of the Telecommunications Act. The features and cost advantages of this technology are likely to attract an increasing number of residential and business subscribers to that type of service further reducing the revenue base. As more communication services migrate towards an IP base transmission there will be fewer carriers providing "telecommunication services," further undermining the revenue base under which the Universal Service Program relies. It is thus not surprising then that some state regulators decided to impose USF contributions on VoIP carriers.

Under the parity scenario where VoIP carriers contribute on an equal basis the Universal Service Program can be maintained for a longer period of time but it is unlikely to be able to sustain the increasing demands that the public wants from this program.

\subsection{Policy implications}

Given that basic telephony has been achieved in the U.S., and taking into consideration the cost of administering the service and the additional cost that this fund poses to subscribers, the benefits of its elimination could exceed the costs. In the absence of a Universal Service Program, the final price for the consumer is likely to be reduced considerably. VoIP subscribers, for example, pay only a dollar more in taxes on top of their monthly subscription. ILEC subscribers, on the other hand, pay as much as \$15 more in taxes and fees, which include universal service contributions; some access charges also go to the universal service fund. In the absence of these fees, and by letting competition reduce the price of basic and advanced services, users will be able to afford them even without a subsidy. This is the type of creative destruction that we believe needs to happen for the 
population of the U.S. to realize the benefits from innovation. It is also possible that software-based telephony will more easily be able to respond to the needs of the users, giving them more control and possibilities as described by Gillett (2000), and even facilitating access for people with disabilities (Goggin and Newell, 2000), given that computer - rather than specialized equipment - are more likely to offer the aid that they need.

There are now numerous examples of this trend. In Grand Haven, MI, for example, the Ottawa Wireless company is building a Wi-Fi network that will be able to provide highspeed data and VoIP services throughout a 6-square-mile radius in packages that range from $\$ 20$ to $\$ 30$ a month. Similarly in Daytona, FL, Craig McCaw is building a wireless network to cover about 65,000 homes. This $1.5 \mathrm{Mbps}$ connections will cost $\$ 25$ a month. With a still experimental technology the town of Manassas, VA is using the town's power lines to deliver a $300 \mathrm{kbps}$ connection to its residents. The price for the service is $\$ 29$, which is considerably cheaper than the $\$ 46$ that Comcast offers for a cable modem connection. These examples show that broadband, which is necessary for VoIP to work, can be obtained at reasonable prices.

How can the universal service fund be eliminated? It is important to realize that while the bulk of the universal service revenues go to major telecommunication operators such as Bell South, many small rural carriers depend for their survival on the funds that the universal service fund provides them every year. These, for the most part, are small local monopolies that, in the absence of competition, have not had much incentive to innovate. How can these companies survive in the absence of the fund, and, more importantly, how can we ensure that rural households continue to receive services? One alternative is a gradual reduction of subsidies to give these carriers time to adjust their practices and to incorporate more efficient technologies, including, for example, VoIP and WiFi networks. Another alternative, would be for all communication and data carriers to contribute to the universal service fund. This will increase the revenue base for the universal service fund but it may be at the expense of emerging technologies that could achieve similar and perhaps better results.

If the FCC decides to maintain the program and implement asymmetric contributions, or even eliminate contributions for new technology, incumbent and new entrants are likely to engage in legal play (Garcia-Murillo, 2004) and further delay the benefits of this disruptive technology.

\section{Conclusions and implications}

In this paper, we argue that new communication technologies such as Internet telephony are likely to be disruptive. Traditional carriers delayed the introduction of this technology because of their because of their privileged quasi-monopoly status and the fact that it is not easy for them to cannibalize their products by offering inexpensive alternatives that offer greater value to the consumer. While many carriers are beginning to offer Internet phone services, the rapidly declining prices even in this new market segment calls into question the sustainability of the carriers' business models, whether for new entrant or established carriers alike (McKnight and Leida 2001, Young, 2005). The entry of new competitors and new technologies is causing a process of creative destruction where prices experience a significant decline and services offered are also more sophisticated, giving control to the user and offering multiple possibilities to disabled individuals. 
Given present regulations, carriers have to decide whether to upgrade or maintain their circuit switched infrastructure. They have to decide between revenues from interconnection and access charges or revenues from enhanced services. The movement has been towards the adoption of IP based networks. Several telecommunications carriers such as Verizon and SBC have begun to provide VoIP services. In May 2005 the FCC rejected an SBC petition to exempt IP platforms from rules and regulations that apply to common carriers. These decisions put traditional carriers at a price disadvantage because they have to include regulatory fees in their tariffs to consumers. It is thus likely that they will continue to put pressure on the commission to exempt them from Title II regulations for all of those services that are IP based.

The greatest challenge for allowing this process of creative destruction to continue is existing regulation and the potential future regulation of VoIP. FCC officials have different alternatives. They could, for example, exempt VoIP from contributing to the USP. They could impose universal service obligations, even if at a lower percentage, to foster its growth. In both of these scenarios it is likely that new players will engage in legal play to prevent the imposition of these obligations. These delays, along with the increase in VoIP prices that results from administration of the fund and the administration of the contributions, will slow the process of creative destruction.

The alternative to these two scenarios is the elimination of the Universal Service Program as a mechanism to fund telephony for residential users and value-added services for libraries, schools and rural health clinics. The simulations show that the universal service fund will not have enough resources even if the VoIP carriers contribute. If instead the program is eliminated, we anticipate that prices will continue to decline to the point that phone service is affordable for everybody, due to the cost savings associated with regulatory compliance, the fees for the USP and continued technological advance.

If the price is not sufficiently low, libraries and schools could join together to negotiate lower prices. The greatest challenge for this scenario is the path-dependent regulation that affects this industry. A change of scenario will require a change in the Telecommunications Act. Additionally, state governments face political opposition from their constituencies. They are also unlikely to want to forego the revenues that this program generates.

Given that a change of such magnitude is not easy to accomplish, and given that the contributions from the new entrants is too small to make a difference in the universal service fund, the FCC could leave VoIP unregulated and then allow existing carriers to migrate from traditional to IP telephony, which will not be regulated. This is a back door entry to the unregulated scenario.

We thus conclude that the existing Universal Service Program should be modified or eliminated allowing some experimentation in the marketplace for the provision of basic and advanced services.

\section{References}

Aizcorbe, A., Flamm, K., and Khurshid, A. (2001) "The Role of Semiconductor Inputs in It Hardware Price Decline: Computers Vs. Communications," Washington, DC: Federal Reserve Board. http://tinyurl.com/bpngd

Albery, B. (1995) "What Level of Dialtone Penetration Constitutes 'Universal Service'?" Telecommunications Policy, 19: 365-380. 
Bar, F., and Riis, A. M. (2000) "Tapping User-Driven Innovation: A New Rationale for Universal Service," Information Society, 16: 99-108.

Baumol, W. J. (2001) "Innovation and Creative Destruction," in McKnight, L., Vaaler, P. M., and Katz, R. (ed.) Creative Destruction: Business Survival Strategies in the Global Internet Economy. Cambridge, MA: MIT Press.

Belinfante, A. (2001) Telephone Subscribership in the United States. Federal Communications Commission: Washington, DC. http://www.fcc.gov/Bureaus/Common_Carrier/Reports/FCC-

State_Link/IAD/subs1100.pdf

Brown, K. (2004) Voip Economics in 2004. Unpublished manuscript, Washington, D.C. http://www.adti.net/telecom/economicsin2004.pdf

Caballero, R. J., and Hammour, M. L. (1996) "On the Timing and Efficiency of Creative Destruction," Quarterly Journal of Economics, 111: 805.

Christensen, C. M. (2000) The Innovator's Dilemma: The Revolutionary National Bestseller That Changed the Way We Do Business. HarperCollins: New York, NY.

Clark, D. D. (2001) "A Taxonomy of Internet Telephony Applications," in McKnight, L. W., Lehr, W. and D.D. Clark (ed.), Internet Telephony. Cambridge, MA: MIT Press.

Federal Communications Commission (2004) Annual Report and Analysis of Competitive Market Conditions with Respect to Commercial Mobile Services. http://hraunfoss.fcc.gov/edocs_public/attachmatch/FCC-04-216A1.pdf

Federal Communications Commission (2005) Proposed Second Quarter 2005 Universal Service Contribution Factor. http://hraunfoss.fcc.gov/edocs_public/attachmatch/DA-05648A1.pdf

Federal Communications Commission (2005) Trends in Telephone Service. http://www.fcc.gov/Bureaus/Common_Carrier/Reports/FCC-State_Link/IAD/trend605.pdf

Garcia-Murillo, M., and Pick, J. (2004) "Interconnection Regulation: Explaining Dominance by Incumbents in Mexico and the United States," Communications and Strategies, 53: 17-52.

Gillett, S. E. (2000) "Universal Service: Defining the Policy Coal in the Age of the Internet," Information Society, 16: 147-149.

Goggin, G., and Newell, C. (2000) "An End to Disabling Policies? Toward Enlightened Universal Service," Information Society, 16: 127-133.

Greenblatt, D. (2003) A Call Heard 'Round the World. AMACON: New York, NY.

Intven, H., Oliver, J., and Sepúlveda, E. (2000) “Competition Policy," in H. Intven (ed.), Telecommunications Regulation Handbook. The World Bank: Washington, DC. 
Lievrouw, L. A. (2000) "The Information Environment and Universal Service," Information Society, 16: 155-159.

McKnight, LW. (2001) "Internet Business Models: Creative Destruction as Usual," in McKnight, L., Vaaler, P. M., and Katz, R. (ed.), Creative Destruction: Business Survival Strategies in the Global Internet Economy. MIT Press: Cambridge, MA.

McKnight, L.W., Leida, B., (2001) "Internet Telephony Service Providers," in McKnight, L.W., Lehr, W. and D.D. Clark (ed.), Internet Telephony. MIT Press: Cambridge, MA.

Mueller, M. (1993) "Universal Service in Telephone History: A Reconstruction," Telecommunications Policy, 17: 352-369.

Stein, J. C. (1997) "Waves of Creative Destruction: Firm-Specific Learning-by-Doing and the Dynamics of Innovation," Review of Economic Studies, 64: 265-288.

Universal Service Administrative Company (2002) Universal Service Administrative Company Annual Report. USAC: Washington, DC. http://tinyurl.com/aqqbf

Universal Service Administrative Company (2003) Universal Service Administrative Company Annual Report. USAC: Washington, DC. http://tinyurl.com/8h713

Universal Service Administrative Company (2004) Universal Service Administrative Company Annual Report. USAC: Washington, DC. http://tinyurl.com/ahmmt

Walsh, S.T., Kirchhoff, B.A., and Newbert, S. (2002) "Differentiating Market Strategies for Disruptive Technologies," IEEE Transactions on Engineering Management, 49: 341351.

Wigfield, M. (2005) "Commission Requires Interconnected Voip Providers to Provide Enhanced 911 Service," FCC: Washington DC. http://hraunfoss.fcc.gov/edocs_public/attachmatch/DOC-258818A1.pdf

World Bank. (2005) World Development Report 2005: A Better Investment Climate for Everybody. World Bank: Washington, D.C. http://web.worldbank.org/WBSITE/EXTERNAL/EXTDEC/EXTRESEARCH/EXTWDRS /EXTWDR2005/0,,menuPK:477681 pagePK:64167702 piPK:64167676 theSitePK:4776 $65,00 . \mathrm{html}$

Young, S. (2005) "Cheap Talk. Market for Internet Calling, Once Tiny, Gets Crowded Fast," The Wall Street Journal, August 26, 2005, Vol. CCLVI No. 40, A1.

Zimmerman, P. R. (2004) Reference Book of Rates, Price Indices, and Household Expenditures for Telephone Service. http://tinyurl.com/d4ste 